\title{
FILOZOFIE PLASTYCZNOŚCI I PRZYGODNOŚCI
}

\section{PRAKTYKA TEORETYCZNA}

Niniejszy numer Praktyki Teoretycznej gromadzi teksty skupione wokół nowych nurtów filozofii materialistycznej, pozwalając uchwycić ich podstawowe problemy i charakterystyczne dla nich pojęcia. Czego chcą dzisiejsze materialistki? - naszym zdaniem prezentowane artykuły zbliżają do odpowiedzi na to pytanie.

Nowy materializm wyłonił się jako próba przezwyciężenia dziedzictwa szeroko rozumianej dekonstrukcji; przezwyciężenia, które byłoby owego dziedzictwa „zniesieniem”: przechowaniem jego intelektualnych zdobyczy w nowej ramie pojęciowej, pozwalającej wykroczyć poza ich dawne słabości. „Etyczny zwrot” w historii dekonstrukcji w szczególności ostatni etap twórczości Derridy, kiedy to problematyka sprawiedliwości, prawa, polityki znalazła się w centrum jego zainteresowania - z dzisiejszej perspektywy wyznacza moment, w którym dekonstrukcja zaczęła ustępować pola nowym próbom teoretycznym. Ich podstawowa motywacja jest przekonanie, że dekonstrukcyjny aparat pojęciowy jest niewystarczający $z$ politycznego punktu widzenia (gdyż, jako antyesencjalistyczny, nie dysponuje dostatecznie mocnym pojęciem zmiany społecznej) i ontologicznie nienowoczesny (gdyż jest w istocie idealizmem obojętnym na najnowsze zdobycze nauk). Elementem spajającym owe zyskujące rozgłos teorie stało się wołanie o odnowiony materializm, który nie przywróci tradycyjnych form esencjalizmu, lecz przekształci same pojęcia tożsamości i esencji, otwierając możliwość ich skutecznej i krytycznej aplikacji.

Po pierwsze, materialistki interesuje pojęcie realnej zmiany. Wielki wysiłek wkładaja w dążenie do osiagnięcia równowagi między wymogiem materialnej ciagłości z jednej strony i wymogiem cięcia, præ̌erwania ciagtości z drugiej. Różne konstrukcje teoretyczne zmierzają ku zachowaniu tej równowagi, próbując uniknać zarzutu, że dopuszczają tylko zmianę pozorną albo pograżaja się w fantazjach o zmianie absolutnej, o wydarzeniach ex nibilo. Na przykład Catherine Malabou szuka własnego rozwiązania tego problemu, używając 
pojęcia „plastyczności”, które ma stanowić odnowienie dialektyki heglowskiej dla potrzeb filozofii współczesnej. W myśli lacanowskiej, której reprezentantką jest Alenka Zupančič, rozwiązania szuka się nade wszystko w „nie-całości”, która - stojąc w opozycji do całości opartej na „konstytutywnym wyjątku” - sama stwarza podstawy swej stałości i przekształcalności.

Po drugie, materialistki interesuje pojęcie przypadku. $\mathrm{Na}$ tym polu jesteśmy świadkami rywalizacji perspektyw, które proponuja odmienne drogi do ugruntowania zasadniczo przygodnego charakteru rzeczywistości. Dla istotnej części debaty wspomniana wyżej nie-całość staje się wspólnym słowem-kluczem, skrywającym jednak dwa radykalnie odmienne pojęcia: jedno daje oparcie materializmowi filozofii psychoanalitycznej, drugie zajmuje centralne miejsce w koncepcji materializmu spekulatywnego, którego przedstawicielem jest Quentin Meillassoux. Ujęcie bliższe teoretyczkom z grupy słoweńskiej, z uwagi na wspólne z nimi heglowskie korzenie, proponuje Malabou, uznając fundamentalną rolę „przypadłości” (akcydensu) w kształtowaniu się tożsamości człowieka.

Po trzecie, materialistki interesuje odnowienie związków filozofii z nauką. Wspólne jest im poczucie, że filozofia powinna śmielej sięgnąć po najnowsze zdobycze rozmaitych nauk, które dotąd były przez nią lekceważone. Dążąc do pozafilozoficznego ugruntowania swoich propozycji, autorki sięgaja do bardzo różnych źródeł - w biologii, w fizyce, w matematyce - w których znajduja pojęcia o znaczeniu daleko wykraczającym poza ich pierwotne dziedziny. Już to daje wyobrażenie o skali różnic między teoriami, które nie godza się ze sobą nawet w tej kwestii, czy w nowej formie materializmu jakąkolwiek rolę pełnić powinno samo pojęcie materii. Zupančič stwierdza wprost, że oparcia dla swojego materializmu nie szuka w prymacie materii, tylko w idei konfliktu. Meillassoux uzasadnia swoje posługiwanie się etykietą materializmu powrotem do wiary w poznawalność „rzeczy samej w sobie". Jednocześnie nowe materialistki zdają sobie sprawę z konieczności uniknięcia mechanicznego przekładania twierdzeń i teorii naukowych na kategorie społeczne. Malabou porusza ten temat w odniesieniu do mechanizmu doboru naturalnego. Cordelia Fine z kolei zwraca uwagę na etyczne konsekwencje stawianych w neuronaukach tez, które dotyczą różnic między kobietami a mężczyznami.

Koncentrujemy się przede wszystkim na teoriach, które wywodzą się z dekonstrukcji i tradycji heglowskiej. Oznacza to oczywiście pominięcie innych nurtów nowego materializmu, w szczególności wywodzących się z ontologii Deleuzjańskiej i tradycji spinozjańskiej; związane z nimi autorki, takie jak Karen Barad, Elizabeth Grosz czy Jane Bennett, są już w pewnym stopniu obecne w polskim pejzażu teoretycznym. Wydaje się, że obydwa te nurty, postheglowski i postspinozjański, stanowią dwie czołowe frakcje dzisiejszych materializmów. Czasem wchodząc w nieoczekiwane sojusze, a innym razem 
generując nieprzekraczalne podziały, ujęcia te powinny stać się przedmiotem dalszych studiów.

Czas pokaże, czy nowe materializmy wyjdą poza etap deklaracji, programów i wstępnych projektów. Obserwujemy je teraz w ich stawaniu się i ścieraniu w walce o ideologiczną dominację. Przekonamy się, które nurty wyjdą z tej rywalizacji zwycięsko i czy rzeczywiście okażą się prawdziwym odnowieniem oraz przekształceniem materializmu jego realną zmianą.

Prezentowane teksty stanowia próby rozmaitych konfrontacji ze streszczonymi powyżej, podstawowymi problemami dzisiejszych materialistek. Numer otwiera prezentacja proponowanego przez Malabou materializmu plastyczności na przykładzie tekstu „Dokąd zmierza materializm? Althusser/Darwin”. Odkryty przez Darwina mechanizm doboru naturalnego może być przekładany na zjawiska społeczne, ale dotychczasowe próby takiego działania czyniły z doboru naturalnego, wbrew spostrzeżeniom samego Darwina, tylko reprodukcję istniejących stosunków, a nie proces ich przekształcania i stwarzania nowych. Alternatywna, „plastyczna” interpretacja doboru szuka jego podstaw, identyfikując społeczne „miejsca nieprzyporządkowane” w świecie, w którym pozornie wszystko jest już na swoim miejscu $-z$ takich miejsc wywodzą się formy nieznane i nieprzewidziane, dokonując „doboru”, który nie aplikuje kryteriów panujących, lecz sam stwarza własne kryteria.

Plastyczny materializm Malabou stanowi inspirację dla Grzegorza Czemiela, który w tekście „Plastic Cartographies” analizuje metafory mapy i terytorium wypracowane przez francuską badaczkę na styku filozofii i neurobiologii. Malabou używa koncepcji kartograficznych, objaśniając swoje pojęcia „plastyczności” oraz „kartografii świata-mózgu”, które pozwalaja jej ująć wzajemną relacje pomiędzy biernym przyjmowaniem formy (byciem zdeterminowanym przez środowisko), a aktywnym nadawaniem formy (przyjmowaniem z zewnatrz tego, co podmiotowość sama sobie przyzna: na swoich, poniekąd, warunkach). Czemiel stosuje narzędzia pochodzące z teorii Malabou do interpretacji wybranych utworów poetyckich Elizabeth Bishop i Nigela Forde'a. Z jednej strony, prowadzi go to do wniosku o zbieżności poetyk tych autorów zarówno z koncepcjami Malabou, jak i z programem ekopoetyki, z drugiej zaś strony, do tezy, że poezja dostarcza form koniecznych do tworzenia lepszych, zrównoważonych „ekologii umysłu” - tj. bardziej wrażliwych i odpowiedzialnych metod przekształcania naszego wspólnego świata.

Drugi dział niniejszego numeru dotyczy wzajemnych relacji tradycji dialektycznej i filozofii plastyczności, na których istotowe powiązanie wielokrotnie wskazuje Malabou. I tak, Maciej Sosnowski w artykule „Plastyczność rewolucji” przygląda się tej relacji na 
przykładzie wskazanego w tytule fenomenu. Autor zauważa, że podwójność wpisana w pojęcie rewolucji - tak w jej wykładni konserwatywnej de Tocqueville’a, jak i socjalistycznej Lukácsa - jest świadectwem ciagłości historycznej, a zarazem jej gwałtownym zerwaniem. Plastyczność autor rozumie - za Malabou - jako współczesną, postdekonstrukcyjną formułę Heglowskiego znoszenia (pasywno-aktywnego formowania, czyli jednoczesnego niszczenia formy i jej zachowywania). Jej istota pokrywa się więc z istotą myślenia o rewolucji zarówno de Tocqueville’a, jak i Lukácsa. Dla Sosnowskiego ta plastyczna dwuznaczność pojęcia staje się przyczyną ostatecznej porażki rewolucji jako realnej zmiany społecznej - triumfuje dialektyczna idea, a fiasko ponosi rewolucyjna rzeczywistość. Uwikłanie rewolucji w przeszłość skazuje ją na bezproduktywny oportunizm, wychylenie w przyszłość - na pusty mesjanizm, a poszukiwanie idealnego zapośredniczenia między tymi skrajnościami zdaje się nie mieć końca.

Problematyka dialektycznego końca jest z kolei przedmiotem tekstu Bartosza Wójcika - „Koniec religii, śmierć Boga, wirtualna wspólnota” - w którym temat ten analizowany jest na przykładzie idei końca religii u Hegla. Rozważania te składają się z trzech etapów: relacji religijnego wyobrażenia i filozofii spekulatywnej, tj. problemu zniesienia religii w filozofii; Heglowskiej wykładni chrześcijaństwa zogniskowanej wokół koncepcji wcielenia jako kenozy, która jest odczytywana według propozycji interpretacyjnej Malabou; idei śmierci Chrystusa jako śmierci samego Boga, która dla Hegla stanowi autentyczny rdzeń chrześcijaństwa. Z Heglowskiej dialektyki końca religii autor próbuje wyprowadzić następującą konkluzję: uśmiercony Bóg zmartwychwstaje w Duchu Świętym, którego historyczna postacią jest „duch obiektywny” - rewolucyjna wspólnota czynów miłości. O ile dla Sosnowskiego rewolucja kończy się tylko na spekulacji, o tyle dla Wójcika spekulacja swój jedyny koniec może mieć właśnie w rewolucji.

Dział trzeci niniejszego numeru stanowi zbiór refleksji nad problemem przypadkowości. W najnowszej filozofii to Quentin Meillassoux ze swoja propozycja „materializmu spekulatywnego” odnowił ontologiczną debatę nad związkami konieczności i przygodności bytu. Od polemiki ze stanowiskiem Meillassoux wychodzi Alenka Zupančič w artykule „Realism in Psychoanalysis”, którego przekład otwiera dział. Autorkę interesuja związki psychoanalizy lacanowskiej z polem współczesnej nauki. Badając je, koncentruje się ona głównie na analizie statusu Realnego w nauce oraz skutków owego statusu dla dyskursu psychoanalitycznego - zastanawia ja, na czym w istocie polega Lacanowskie utożsamienie podmiotu nieświadomości z podmiotem nowożytnej nauki. Psychoanalityczna wersja realizmu - rozwijana przez Zupančič - opiera się na twierdzeniu, że wszelka konieczność jest „nie-cała”, niedomknięta, w przeciwieństwie do dictum Meillassoux, dla którego „konieczność przygodności” posiada status absolutnego wyjątku. 
Krytyka projektu Meillassoux stanowi również oś tematyczną drugiego artykułu z tego działu, „Possibility of Science, Impossibility of Miracles” Tryggviego Örna Úlfssona. Autor szukając, podobnie jak francuski filozof, produktywnych związków nauki i filozofii, odrzuca mimo wszystko materializm spekulatywny - polemizuje zarówno z jego koncepcją nauki, jak i z fundamentalną tezą o koniecznej przygodności. „Zasadzie bezracji” Meillassoux zostaje przeciwstawiona zasada zmiennej racji bądź zmiennego rozumu (principle of a metamorphosing reason), oparta na tezie, że żadna nieredukowalna przygodność nie jest praktycznie możliwa. W ślad za Léonem Brunschvicgiem i Antoine-Augustinem Cournotem autor broni poglądu, że przyrodniczy determinizm nigdy nie ma absolutnego charakteru, gdyż podlega historycznym przekształceniom; lecz dlatego właśnie niemożliwe jest zidentyfikowanie wydarzenia w ścisłym sensie przygodnego - tłem dla takiego wydarzenia mogłaby być tylko sztywna konieczność, z punktu widzenia nauki pojęcie tak samo nieprzydatne jak ścisła przypadkowość.

Problem przygodności, jak już zauważyliśmy, odgrywa także istotną rolę w plastycznej antropologii Malabou. „Przypadłość” w formowaniu się tożsamości może mieć dwa oblicza: pozytywne - twórcza metamorfoza - oraz negatywne - tak zwana „plastyczność destrukcyjna”, która zdaniem Malabou była pomijana w dotychczasowej tradycji filozoficznej, a także w psychoanalizie. Właśnie próbie częściowej obrony teorii psychoanalitycznej przed zarzutami francuskiej filozofki poświęcony jest artykuł Agnieszki Więckiewicz „Ontologia przypadłości »jak gdyby« w teorii Heleny Deutsch”. Autorka dokonuje w nim relektury prac polskiej psychoanalityczki Heleny Deutsch, a przede wszystkim jej teorii osobowości „,jak gdyby” („pasywnej plastyczności”), przyglądając im się przez pryzmat kategorii pojęciowych Malabou. Zestawienie to prowadzi autorkę do konstatacji, że nielinearna, ruchoma - czyli plastyczna - koncepcja podmiotowości stanowiła podstawę myśli Deutsch, w której „,ja” podmiotu zawsze pozostawało nieuchwytne, wymagało od niego pozostawania w ciagłym ruchu i prowadziło ostatecznie do nieustannie ponawianych konfrontacji z samym soba.

W ostatnim, czwartym dziale numeru przyglądamy się społecznym konsekwencjom współczesnej nauki na przykładzie neurofeminizmu, przybliżając czytelniczce poglądy Cordelii Fine. W artykule przełożonym i opatrzonym wstępem przez Aleksandrę Derrę feministyczna badaczka analizuje hipotezę o istnieniu głęboko zakorzenionych różnic między mózgami mężczyzn i kobiet, które przyczyniaja się do powstawania różnic pomiędzy zachowaniami typowymi dla danej płci. Według Fine takie twierdzenia stanowia samospełniająca się przepowiednię, naturalizującą tylko istnienie różnic płciowych. Słowem, rzekomy determinizm biologiczny ma służyć za legitymizację seksistowskich poglądów (neuroseksizm), zgodnie z którymi kobieta z natury jest podrzędna wobec mężczyzny. Dlatego Fine tak duży nacisk kładzie na etyczno-społeczny wymiar współczesnych badań naukowych, który zbyt często bywa pomijany przez samych naukowców. 
CYTOWANIE: Praktyka Teoretyczna. 2018. „Filozofie plastyczności i przygodności.“ Praktyka Teoretyczna 2(28): 8-13.

DOI: $10.14746 /$ prt.2018.2.0

AUTHOR: Theoretical Practice

TITLE: Philosophies of Plasticities and Contingencies

ABSTRACT: A short introduction to the special issue of the Theoretical Practice Journal. 